\title{
Effect of Different Cropping System on Important Soil Enzyme Activity, Organic Carbon and Microbial Activity with Different Depth
}

\author{
V.P. Bhavya, S. Anil Kumar, S.K. Kiran, Ashok Alur, \\ K.M. Shivakumar and M. Shivanna \\ Department of Soil Science and Agricultural Chemistry, College of Horticulture, \\ Bengaluru-560 065, Karnataka, India \\ *Corresponding author
}

\section{A B S T R A C T}

Keywords

Crpping system,

Soil enzyme activity, Depth

Article Info

Accepted:

04 December 2017

Available Online:

10 January 2018
The microbial and enzyme activities of the soil are closely related to the organic matter content and influenced by hydrothermal regimes of the soil. Keeping this in view, the study conducted that effect of different cropping systems on dehydrogenase, urease, acid and alkaline phosphatase activity and microbial population like bacteria, fungi and actinimycetes was evaluated from $>20$ year old cultivation under different cropping systems i.e., mango, cashew, vegetable, rose and medicinal and aromatic crops at different depths $(0-15,15-$ 30, 30-50. 50-100 cm). From this study it was observed that, the mango and cashew showed significantly higher enzymes activity and microbial population at surface soil $(0-15 \mathrm{~cm})$ as compared to annual crops.

\section{Introduction}

The term soil organic matter has been used to encompass all organic materials found in soil (Stevenson, 1994) and partial decomposed products and non-decayed plant and animal tissues.

Organic matter inputs through organic amendments, in addition to supplying nutrients, stimulate microbial diversity and activity and improved soil aggregation, which had positive effects on soil water content, temperature, aeration and mechanical impedance (Ferreras et al., 2006). Enzymes are the micro-organisms which catalyses the reaction without any changes. Generally, the enzyme activities in the soil are closely related to the organic matter content and strongly influenced by the hydrothermal regimes, enzymes catalyze all biochemical reactions and are an integral part of nutrient cycling in soil and these are sensitive indicators of soil ecological stress or other environmental changes (Marinari et al., 2006).

Microorganisms play a major role on decomposition of several organic compounds frequently used in agriculture, which directly affect the synthesis and decomposition of soil 
organic matter (Carney and Matson, 2005). The main microbial enzymes involved in the mineralization of soil organic matter are cellulases, dehydrogenases, acid and alkaline phosphatise activity, proteases, nitrogen fertilization is the most important management strategy for the improvement of agricultural crops. Urea is the most widely used source of organic $\mathrm{N}$ fertilizer in the world, which is easily hydrolyzed to ammonium and carbon dioxide by urease enzyme (Masciandaro and Ceccanti, 1999; Kunito et al., 2001). The main objective of this study was to assess the effect of different cropping systems on soil enzyme activity, organic carbon and microbial activity with different depth.

\section{Materials and Methods}

The present investigation was carried out at Horticulture division, UAS Campus GKVK, Bengaluru, Karnataka during 2015. The soil of the experimental site was sandy loam and classified as fine, mixed isothermic Kandic Paleustalf of Vijayapura soil series. Cultivation of horticultural crops viz., mango, cashew, rose, vegetables and medicinal and aromatic crops were selected for the experiment within the same locality. The experimental plots were permanently laid out for specified crops.

There is no change either in the cropping system or in the fertilizer management practices since the planting. In each sampling site, soil samples were collected from four different depths i.e., 0-15, 15-30, 30-50, and $50-100 \mathrm{~cm}$.

Soil samples were processed by drying under the shade, powdering with a clean wooden mallet and passing through a $2 \mathrm{~mm}$ sieve. The processed samples were stored in polyethylene bags for analysis in the laboratory. The statistical analysis was done by using Randamized Complete Block Design (RCBD).

\section{Analysis of the soil sample}

\section{Organic carbon}

A known weight $(0.5 \mathrm{~g})$ of $0.2 \mathrm{~mm}$ sieved soil was treated with a known excess volume of chromic acid $\left(\mathrm{K}_{2} \mathrm{Cr}_{2} \mathrm{O}_{7}+\mathrm{H}_{2} \mathrm{SO}_{4}\right)$.

After the oxidation of organic carbon, the unreacted $\mathrm{K}_{2} \mathrm{Cr}_{2} \mathrm{O}_{7}$ left in the contents was back titrated with standard ferrous ammonium sulphate using diphenylamine indicator (Walkley and Black, 1934).

\section{Analysis of soil samples for biological properties}

\section{Pre-incubation}

Pre-incubation of soil samples was done to restore the normal biological activities. A known quantity of soil was moistened to field capacity (60\% of MWHC) and incubated at 37 $\pm 2{ }^{0} \mathrm{C}$ in a BOD incubator, three days for dehydrogenise and 7 days for phosphatase.

The samples incubated were adopted to bring back to the original levels of biological activity (Basavaraj, 1984).

\section{Enumeration microbial population}

The enumeration of total bacteria, fungi, and actinomycetes, in the samples was carried out by following the standard dilution plate count technique.

Soil extract agar for bacteria, Martin's Rose Bengal streptomycin sulphate agar for fungi, and Kuster's agar for actinomycetes, were used for enumeration.

The petriplates were incubated at $30^{\circ} \mathrm{C}$ for six days and population was counted and expressed per unit dry weight of substrate (Kumar, 2015). 


\section{Results and Discussion}

\section{Soil organic carbon under different land use systems}

Organic carbon content at different depths as influenced by different horticulture crops is presented in figure 1 .

The organic carbon content of soil was higher in the surface layer of the soil i.e., $0-15 \mathrm{~cm}$ as compared to other subsurface soil depth in all the cropping systems. The carbon content differed significantly with different cropping systems; the mango orchard had higher organic carbon content i.e., 7500.00, 7334.00, 7016.00 , and $6743.00 \mathrm{mg} \mathrm{kg}^{-1}$ at $0-15 \mathrm{~cm}, 15-$ $30 \mathrm{~cm}, 30-50 \mathrm{~cm}$ and $50-100 \mathrm{~cm}$ depths respectively which was followed by cashew orchard. However the medicinal and aromatic block had lowest organic carbon 4521.00, $4311.00,4008.00$ and $3933.00 \mathrm{mg} \mathrm{kg}^{-1}$ at $0-15$ $\mathrm{cm}, 15-30 \mathrm{~cm}, 30-50 \mathrm{~cm}$ and $50-100 \mathrm{~cm}$ depths respectively.

This is due to the continuous addition of organic matter in perennials crops like mango and cashew orchard which leads to accumulate more organic matter to the soil and thereby it helps to increase the carbon content in soil.

Since organic manures are incorporated in to the surface soil and a major portion of the left over residues of shallow rooted crops usually accumulate in the top few centimetre of the soil layers, there was possibility for a relatively greater accumulation of organic carbon in $0-15 \mathrm{~cm}$ soil as compared to the soils of lower layer.

Similar results were obtained by Manjaiah et al., (2000). Increase in soil carbon due to continuous addition of bio mass through leaf and roots have been reported by Geo Jose (2006) in case of field crops and by Krishnappa Naik et al., (1998).

\section{Dehydrogenase activity under different land use systems}

The dehydrogenase activity differed from one depth to other soil depth. The higher dehydrogenase activity was observed at 0-15 $\mathrm{cm}$ and lowest was observed in the $15-30 \mathrm{~cm}$, $30-50 \mathrm{~cm}$ and $50-100 \mathrm{~cm}$. The dehydrogenase activity was decreased with increase in soil depths (Table 1). Among different cropping systems, mango had maximum dehydrogenase activity (680.78 $\mu \mathrm{g}$ TPF $\mathrm{g}^{-1}$ soil) which is on par with the cashew $\left(660.44 \mu \mathrm{g}\right.$ TPF $\mathrm{g}^{-1}$ soil) which was highly significant from rose block (524.64 $\mu \mathrm{g}$ TPF $\mathrm{g}^{-1}$ soil), vegetable block (521.44 $\mu \mathrm{g}$ TPF $\mathrm{g}^{-1}$ soil) and medicinal and aromatic block (500.46 $\mu \mathrm{g}$ TPF $\mathrm{g}^{-1}$ soil) with twenty year old cultivated soil.

\section{Urease activity under different land use systems}

The urease activity differed at different soil depths. The higher urease activity was observed in the $0-15 \mathrm{~cm}$ and lowest was observed in the deeper layer i.e., $15-30 \mathrm{~cm}$, $30-50 \mathrm{~cm}$ and $50-100 \mathrm{~cm}$ (Table 2).

Among different cropping systems, the cashew orchard had higher urease activity (1374.17 $\mu \mathrm{g} \mathrm{PNP} \mathrm{g}^{-1}$ soil) which is on par with the mango orchard (1345.17 $\mu \mathrm{g}$ PNP $\mathrm{g}^{-1}$ soil) and it was highly significant from rose block (1000.11 $\mu \mathrm{g}$ PNP $\mathrm{g}^{-1}$ soil), vegetable block (980.66 $\mu \mathrm{g}$ PNP $\mathrm{g}^{-1}$ soil) and medicinal and aromatic block (990.13 $\mu \mathrm{g} \mathrm{PNP} \mathrm{g}^{-1}$ soil).

\section{Acid phosphatise activity under different land use systems}

The acid phosphatase activity decrease with increased in soil depths. The higher acid phosphatase activity was observed in the 0-15 $\mathrm{cm}$ depth and lowest was observed in the subsurface layer of the soil i.e., $15-30 \mathrm{~cm}, 30$ $50 \mathrm{~cm}$ and $50-100 \mathrm{~cm}$ (Table 3). 
Table.1 Dehydrogenase activity at different depths as influenced by different horticulture crops

\begin{tabular}{|c|c|c|c|c|}
\hline \multirow{3}{*}{$\begin{array}{l}\text { Horticulture land } \\
\text { use system }\end{array}$} & \multicolumn{4}{|c|}{$>20$ year old cultivation } \\
\hline & \multicolumn{4}{|c|}{ Dehydrogenase activity ( $\mu \mathrm{g}$ TPF $\mathrm{g}^{-1}$ soil) } \\
\hline & $0-15 \mathrm{~cm}$ & $15-30 \mathrm{~cm}$ & $30-50 \mathrm{~cm}$ & $\begin{array}{l}50-100 \\
\mathrm{~cm}\end{array}$ \\
\hline Mango orchard & 680.78 & 653.14 & 634.17 & 560.44 \\
\hline Cashew orchard & 660.44 & 643.18 & 624.16 & 540.73 \\
\hline Rose block & 524.64 & 498.13 & 484.31 & 458.14 \\
\hline Vegetable block & 521.44 & 489.76 & 470.33 & 449.83 \\
\hline $\begin{array}{l}\text { Medicinal and } \\
\text { aromatic block }\end{array}$ & 500.46 & 480.33 & 458.84 & 440.52 \\
\hline SEm \pm & 33.11 & 30.32 & 29.65 & 27.24 \\
\hline CD at $5 \%$ & 96.55 & 92.11 & 89.56 & 83.11 \\
\hline
\end{tabular}

Table.2 Urease activity at different depths as influenced by different horticulture crops

\begin{tabular}{|c|}
\hline $\begin{array}{l}\text { Horticulture land } \\
\text { use system }\end{array}$ \\
\hline Mango orchard \\
\hline Cashew orchard \\
\hline Rose block \\
\hline Vegetable block \\
\hline $\begin{array}{l}\text { Medicinal and } \\
\text { aromatic block }\end{array}$ \\
\hline $\begin{array}{r}\text { SEm } \pm \\
\text { CD at 5\% }\end{array}$ \\
\hline
\end{tabular}

\begin{tabular}{|c|c|c|c|}
\hline \multicolumn{4}{|c|}{$>20$ year old cultivation } \\
\hline $0-15 \mathrm{~cm}$ & $15-30 \mathrm{~cm}$ & $30-50 \mathrm{~cm}$ & $50-100 \mathrm{~cm}$ \\
\hline 1345.17 & 1286.32 & 1008.36 & 880.78 \\
\hline 1374.18 & 1238.14 & 1000.84 & 877.25 \\
\hline 1000.11 & 990.77 & 943.64 & 826.78 \\
\hline 980.66 & 958.14 & 928.32 & 830.40 \\
\hline 990.13 & 963.38 & 948.78 & 827.38 \\
\hline 63.44 & 60.56 & 53.12 & 42.15 \\
\hline 190.34 & 181.12 & 160.12 & 142.23 \\
\hline
\end{tabular}

Table.3 Acid phosphatase activity at different depths as influenced by Different horticulture crops

\begin{tabular}{l} 
Horticulture land \\
use system \\
\hline Mango orchard \\
\hline Cashew orchard \\
\hline Rose block \\
\hline Vegetable block \\
\hline $\begin{array}{r}\text { Medicinal and } \\
\text { aromatic block SEm } \pm \\
\hline \text { CD at 5\% }\end{array}$ \\
\hline
\end{tabular}

\begin{tabular}{|c|c|c|c|}
\hline \multicolumn{4}{|c|}{$>20$ year old cultivation } \\
\hline \multicolumn{3}{|c|}{ Acid phosphatase activity $\left(\mu \mathrm{g}\right.$ PNP g $^{-1}$ soil $)$} \\
\hline $0-15 \mathrm{~cm}$ & $15-30 \mathrm{~cm}$ & $30-50 \mathrm{~cm}$ & $50-100 \mathrm{~cm}$ \\
\hline 104.21 & 98.31 & 88.31 & 86.34 \\
\hline 100.31 & 96.32 & 90.31 & 85.31 \\
\hline 70.33 & 65.28 & 60.33 & 54.33 \\
\hline 68.31 & 63.76 & 62.11 & 55.34 \\
\hline 67.83 & 65.76 & 60.26 & 53.14 \\
\hline 4.66 & 4.44 & 4.12 & 3.78 \\
\hline 13.45 & 12.96 & 12.04 & 11.28 \\
\hline
\end{tabular}


Table.4 Alkaline phosphatase activity at different depths as influenced by Different horticulture crops

\begin{tabular}{l} 
Horticulture land \\
use system \\
\hline Mango orchard \\
\hline Cashew orchard \\
\hline Rose block \\
\hline Vegetable block \\
\hline Medicinal and aromatic block \\
\hline CD at $5 \%$ \\
\hline
\end{tabular}

\begin{tabular}{|c|c|c|c|}
\hline \multicolumn{5}{|c|}{$>20$ year old cultivation } \\
\hline Alkaline phosphatase activity $(\mu \mathrm{g}$ PNP g \\
\hline $0-15 \mathrm{~cm}$ & $15-30 \mathrm{~cm}$ & $30-50 \mathrm{~cm}$ & $50-100 \mathrm{~cm}$ \\
\hline 50.17 & 45.28 & 40.28 & 35.78 \\
\hline 49.88 & 44.84 & 39.26 & 34.98 \\
\hline 36.44 & 33.41 & 30.44 & 28.44 \\
\hline 35.28 & 32.46 & 28.78 & 26.56 \\
\hline 34.84 & 31.98 & 29.43 & 25.88 \\
\hline 2.29 & 2.08 & 1.86 & 1.68 \\
\hline 6.88 & 6.26 & 5.60 & 5.05 \\
\hline
\end{tabular}

Table.5 Actinomycetes population at different depths as influenced by Different horticulture crops

\begin{tabular}{l} 
Horticulture land \\
use system \\
\hline Mango orchard \\
\hline Cashew orchard \\
\hline Rose block \\
\hline Vegetable block \\
\hline Medicinal and aromatic block \\
\hline CD at $5 \%$ \\
\hline
\end{tabular}

\begin{tabular}{|c|c|c|c|}
\hline \multicolumn{4}{|c|}{$>20$ year old cultivation } \\
\hline \multicolumn{2}{|c|}{ Actinomycetes population $\left(\mathrm{CFU} \times 10^{3} \mathrm{~g}^{-1}\right.$ soil) } \\
\hline $0-15 \mathrm{~cm}$ & $15-30 \mathrm{~cm}$ & $30-50 \mathrm{~cm}$ & $50-100 \mathrm{~cm}$ \\
\hline 0.96 & 0.90 & 0.42 & 0.30 \\
\hline 0.92 & 0.89 & 0.40 & 0.28 \\
\hline 0.60 & 0.40 & 0.28 & 0.14 \\
\hline 0.58 & 0.38 & 0.29 & 0.15 \\
\hline 0.57 & 0.39 & 0.30 & 0.18 \\
\hline 0.28 & 0.03 & 0.02 & 0.02 \\
\hline 0.77 & 0.09 & 0.06 & 0.06 \\
\hline
\end{tabular}

Fig.1 MO- Mango Orchard, VB- Vegetable Block, CO- Cashew Orchard, MAP's- Medicinal and Aromatic Plants, RB- Rose Block

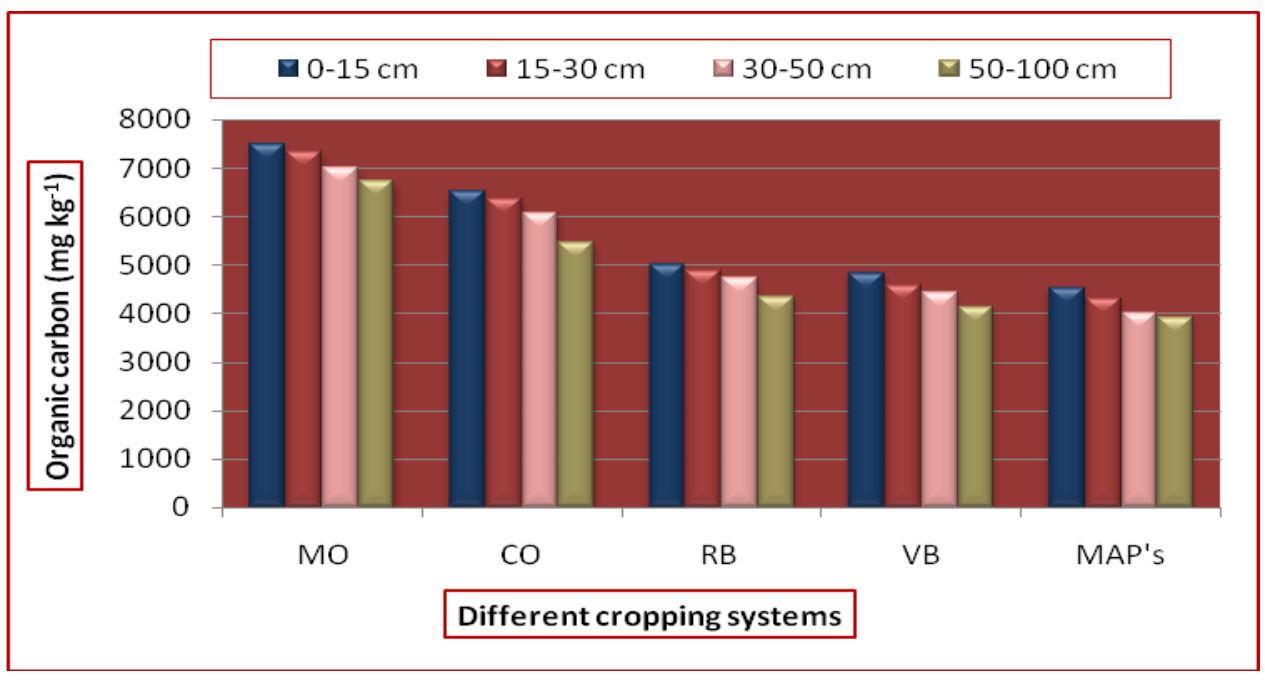


Fig.2 Bacterial population at different depth as influenced by different horticulture crops

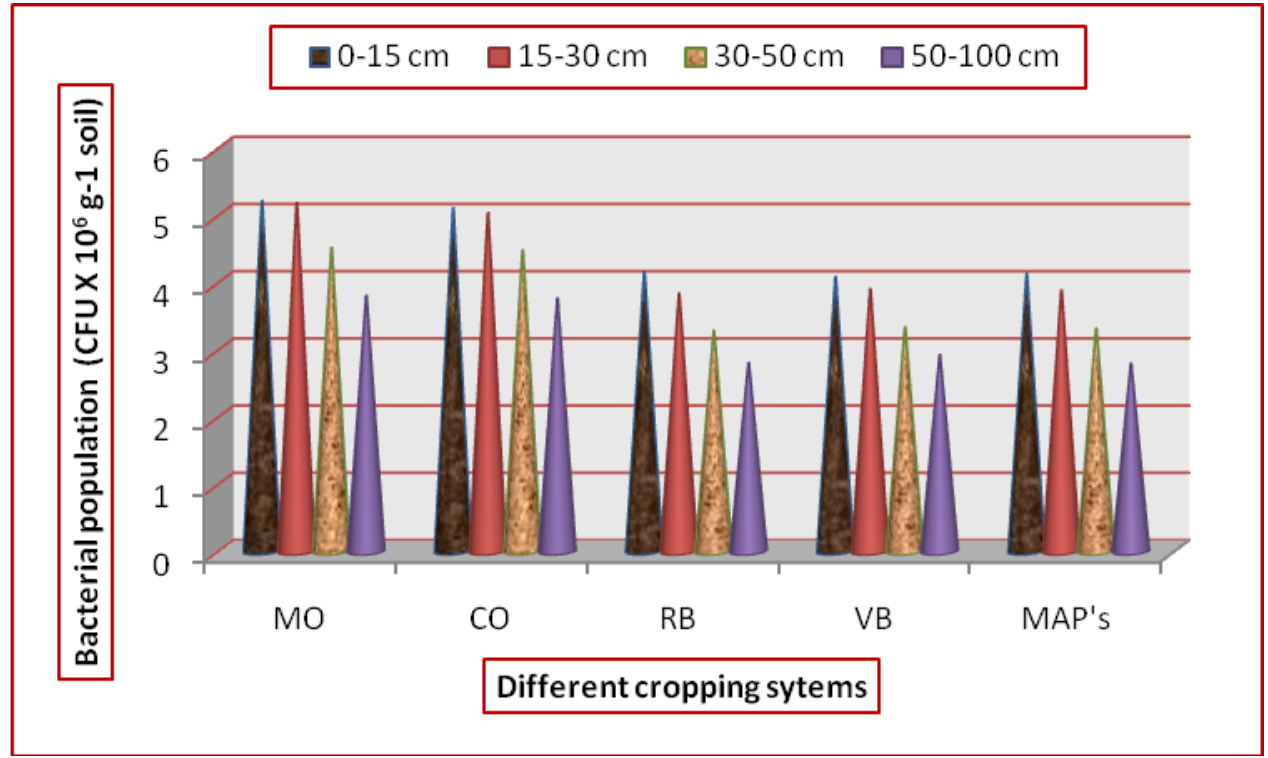

MO- Mango Orchard, VB- Vegetable Block, CO- Cashew Orchard, MAP's- Medicinal and Aromatic Plants, RBRose Block.

Among different cropping systems, the mango orchard had the maximum acid phosphatase activity (104.21 $\mu \mathrm{g}$ PNP $\mathrm{g}^{-1}$ soil) which is on par with the cashew orchard (100.31 $\mu \mathrm{g}$ PNP $\mathrm{g}^{-1}$ soil) and it is highly significant from rose block $\left(70.33 \mu \mathrm{g} \mathrm{PNP} \mathrm{g}^{-1}\right.$ soil), vegetable block (68.31 $\mu \mathrm{g}$ PNP g ${ }^{-1}$ soil) and medicinal and aromatic block $(67.83 \mu \mathrm{g}$ PNP $\mathrm{g}^{-1}$ soil) respectively.

\section{Alkaline phosphatase activity under different land use systems}

The higher alkaline phosphatase activity was observed in the $0-15 \mathrm{~cm}$ depth and lowest was observed in the subsurface layer of the soil i.e., $15-30 \mathrm{~cm}, 30-50 \mathrm{~cm}$ and $50-100 \mathrm{~cm}$ (Table 4). Among different cropping systems, the mango orchard had the maximum alkaline phosphatase activity $\left(50.17 \mu \mathrm{g}\right.$ PNP $\mathrm{g}^{-1}$ soil) which is on par with the cashew orchard (49.88 $\mu \mathrm{g}$ PNP $\mathrm{g}^{-1}$ soil) and it is highly significant from rose block (36.44 $\mu \mathrm{g}^{\mathrm{PNP}} \mathrm{g}^{-1}$ soil), vegetable block (35.28 $\mu \mathrm{g}$ PNP $\mathrm{g}^{-1}$ soil) and medicinal and aromatic block (34.84 $\mu \mathrm{g}$
PNP $\mathrm{g}^{-1}$ soil) respectively. This may be due to the fact that soil enzymatic activity was generally higher at the surface soil owing to higher organic matter and availability of more nutrients by continuous addition of organic matter with minimum tillage treatments which has a synergizing effect on enzymatic activity in upper layer of the soil than in deeper depths. However in the subsurface layers of the soil, as the depth increases the compaction of soil will be more which has less organic matter and nutrients which recorded the lowest enzymatic activity.

\section{Soil microbial population}

\section{Bacterial population under different land use systems}

In four year old cultivated soil, the bacterial population was differed at different depth of the soil (Fig. 2). 0-15 cm soil depth showed higher bacterial population and lowest was observed in the subsurface layer of the soil i.e., $15-30 \mathrm{~cm}, 30-50 \mathrm{~cm}$ and $50-100 \mathrm{~cm}$. The bacterial population decreased with increased 
in soil depth. Among different cropping systems, the mango orchard (5.21 CFU X $10^{6}$ $\mathrm{g}^{-1}$ soil) showed maximum bacterial population which is on par with the cashew orchard (5.10 CFU X $10^{6} \mathrm{~g}^{-1}$ soil) and it is highly significant from rose block (4.16 CFU $\mathrm{X} 10^{6} \mathrm{~g}^{-1}$ soil), vegetable block (4.08CFU X $10^{6} \mathrm{~g}^{-1}$ soil) and medicinal and aromatic block (1.02CFU X $10^{6} \mathrm{~g}^{-1}$ soil).

\section{Actinomycetes population under different land use systems}

The actinomycetes population decreased with increase in soil depths. $0-15 \mathrm{~cm}$ soil depth showed highest actinomycetes population and lowest was observed in the subsurface layer of the soil i.e., $15-30 \mathrm{~cm}, 30-50 \mathrm{~cm}$ and $50-$ $100 \mathrm{~cm}$ (Table 5). Among different cropping systems, the maximum actinomycetes population was recorded under the mango orchard $\left(0.96 \mathrm{CFU} \mathrm{X} \mathrm{10} 0^{3} \mathrm{~g}^{-1}\right.$ soil) which is on par with the cashew orchard $\left(0.92 \mathrm{CFU} \mathrm{X} 10^{3}\right.$ $\mathrm{g}^{-1}$ soil) followed by rose block (0.60 CFU X $10^{3} \mathrm{~g}^{-1}$ soil $)$, vegetable block $\left(0.58 \mathrm{CFU} \times 10^{3}\right.$ $\mathrm{g}^{-1}$ soil) with four old cultivation.

The bacteria and actinomycetes populations were maximum in the upper layer of the soil and lowest was recorded in the deeper layers, the populations of bacteria and actinomycetes were decreased with increase soil depths. This may be due to the fact that soil bacteria and actinomycetes populations is generally higher at the surface soil owing to higher organic matter and availability of more nutrients which act as a source for their food for their survival by continuous addition of organic matter with minimum tillage treatments than in deeper depths. However, in the subsurface layers of the soil, as the depth increase the compaction of soil will be more which has less organic matter and less nutrients which recorded the lowest microbial populations. Velmourougane et al., (2014) reported that the microbial population declined with depth and maximum activity was recorded within $0-30 \mathrm{~cm}$ soil depth.

The fungal populations were slightly higher in the surface layers as compared to the subsurface layers. In this study, the fungal population showed non-significant results in all the cropping systems and in all the depths. This is due to the, the soil $\mathrm{pH}$ under the selected horticultural crops at horticulture division, UAS campus, Bengaluru was neutral i.e., 6.5-7.5. However, the fungal growth will be more in the acidic soil which is having soil $\mathrm{pH}$ less than 5.5 showed non-significant results in all the cropping systems.

The mango and cashew orchard had higher soil carbon content, enzymes activity and microbial population at $0-15 \mathrm{~cm}$ as compared to the annual crops. Because the surface soil had higher carbon content and availability of more nutrients which act as a source for their food for their survival by continuous accumulation of organic matter with minimum tillage treatments under the perennial crops than in deeper depths. However, in the subsurface layers as the depth increase the compaction of soil will be more which has less organic matter, carbon content and less nutrients.

\section{References}

Basavaraj, B., 1984. Effect of pesticides on the activity of urease, phosphatise and dehydrogenase in black and red soils of Karnataka. M.Sc. (Agri), Thesis, USA, Bengaluru.

Carney, K.M., and Matson, P. A., 2005. Plant communities, soil microorganisms, and soil carbon cycling: does altering the world belowground matter to ecosystem functioning? Ecosystem, 8: 928-940.

Ferreras, L., Gómez, Toresani, S., Firpo, L. and Rotondo, R., 2006. Effect of organic amendments on some physical, 
chemical and biological properties in a horticultural soil. Bioresour. Technol. 97: 635-640.

Krishnappa Naik, C. S., Haricharan, B. R., Jayarama and Surendra Swamy, H. B., 1998. Coffee soils of Chikmagalur district. Indian Coffee, 52(10): 3-9.

Kumar, Y. A., 2014. Practical microbiology, Anmol publication, pp 45.

Kunito, T., Saeki, K., Goto, S., Hayashi, H., Oyaizu, H., and Matsumoto, S., Copper and zinc fractions affecting microorganisms in long-term sludgeamended soils. Bioresource Technology, v.79, p.135-146, 2001

Manjaiah, K. M., Voroney, R.P., and Sen, U., 2000. Soil organic carbon stocks, storage profile and microbial biomass under different crop management systems in a tropical agricultural ecosystem. Biol. Fertil. Soils, 31: 273-
278.

Marinari, S., Mancinelli, R., Campiglia, E., and Grego, S., 2006. Chemical and biological indicators of soil quality in organic and conventional farming systems in Central Italy. Ecol. Indicators. 6: 701-711.

Masciandaro, G., and Ceccanti, B., 1999. Assessing soil quality in different agroecosystems through biochemical and chemico structural properties of humic substances. Soil and Tillage Research, v.51, p.129-13.

Walkey, A. J. and Black, C. A., 1934. An extraction method of degtijar method for determining soil organic matter and proposed modification chromic acid titration method. J Soil Sci., 37: 29-38.

Wlodarczyk, T., 2000. Some of aspects of dehydrogenase activity in soils. Int. Agrophysics. 14: 365-376.

\section{How to cite this article:}

Bhavya, V.P., S. Anil Kumar, S.K. Kiran, Ashok Alur, K.M. Shivakumar and Shivanna, M. 2018. Effect of Different Cropping System on Important Soil Enzyme Activity, Organic Carbon and Microbial Activity with Different Depth. Int.J.Curr.Microbiol.App.Sci. 7(01): 315322. doi: https://doi.org/10.20546/ijcmas.2018.701.034 